\title{
Pengembangan Sistem Informasi Geografis Berbasis Web Untuk Pariwisata dan Budaya di Pulau Lombok
}

\author{
Febriyan Adhiatma ${ }^{\mathrm{a}, 1}$, Tedy Setiadi (0407016801) $)^{\mathrm{a}, 2}$ \\ 1,2Program Studi Teknik Informatika Universitas Ahmad Dahlan \\ J1. Ringroad Selatan, Kragilan, Tamanan, Kec. Banguntapan, Bantul,,Yogyakarta 55191 \\ ${ }^{1}$ Email : atma10018116@gmail.com ${ }^{2}$ Email : tedy.setiadi@tif.uad.ac.id
}

\section{ABSTRAK}

Nusa Tengga Barat adalah sebuah provinsi di Indonesia yang berada dalam kelompok sunda kecil dan termasuk di pulau Nusa Tenggara. Provinsi ini memiliki 10 kabupaten atau kota. Dua pulau terbesar di provinsi ini adalah Pulau Lombok yang terletak di sebelah barat dan Pulau Sumbawa yang terletak di sebelah timur. Ibukota provinsi ini adalah kota mataram yang terletak di pulau Lombok. Dengan bentuk kepulauan, Nusa Tenggara Barat memiliki begitu banyak tujuan wisata yang indah, terutama di Pulau Lombok. Selain sektor pariwisata yang dimiliki, Pulau Lombok juga memiliki beragam budaya yang masih merupakan festival tahunan yang dilakukan oleh masyarakat setempat.

Dalam penelitian ini, objek penelitian adalah pembuatan sistem informasi geografis untuk pariwisata dan budaya. Metode pengumpulan data dengan metode observasi dan metode wawancara. Perancangan sistem menggunakan UML untuk menggambarkan proses apa yang terjadi pada sistem, sehingga bisa mendapatkan gambaran atau langkah kerja yang dapat digunakan untuk membuat sistem terstruktur seperti Use Case Diagram, Activity Diagram, Sequence Diagram to Class Diagram

Dari penelitian yang dilakukan untuk menghasilkan perangkat lunak sistem informasi geografis berbasis web untuk pariwisata dan budaya di pulau Lombok dengan kemampuan untuk memberikan informasi mengenai lokasi wisata yang ada di pulau Lombok, memberikan panduan atau rute jalan menuju tempat-tempat wisata, budaya, makanan, hotel, panduan dan acara dan menampilkan deskripsi tur, budaya, hotel, makanan, pemandu, acara. Dari hasil pengujian sistem menunjukkan bahwa aplikasi tersebut layak dan bisa digunakan.

Ciptaan disebarluaskan di bawah lisensi CC-BY-SA

Kata Kunci : Sistem Informasi Geografis, Pariwisata dan Budaya, Pulau Lombok

\section{Pendahuluan}

Nusa Tenggara Barat merupakan sebuah provinsi di Indonesia yang berada dalam gugusan sunda kecil dan termasuk dalam kepulauan Nusa Tenggara. Nusa Tenggara Barat yang terdiri dari 2 pulau, yakni pulau Lombok dan Pulau Sumbawa memiliki daya tarik tersendiri di sektor wisata dan budaya yang masih sangat kental.

Di sektor wisata misalnya, pulau Lombok Dan pulau Sumbawa masing-masing memiliki banyak sekali tempat wisata. Namun, pulau Lombok masih menjadi sasaran utama para wisatawan karena selain tempat yang strategis, pilihan wisata yang sangat indah dan akses wilayah yang mudah sehingga pulau Lombok menjadi sasaran utama wisatawan untuk berwisata. Berbagai destinasi wisata yang menjadi pusat kunjungan antara lain : Gili Trawangan yang terletak di Kabupaten Lombok Utara, pantai pink, pantai bloam yang terletak di Kabupaten Lombok Timur, pantai Senggigi yang terletak di Kabupaten Kota Mataram, Air terjun benang kelambu dan Pantai Kuta yang terletak di Kabupaten Lombok Tengah, dan banyak lagi destinasi wisata baru yang ada di pulau Lombok.[2]

Namun, dari sekian banyak tempat wisata yang ada di pulau lombok, wisatawan masih sangat kesulitan untuk mencari lokasi wisata yang ingin dikunjungi, terutama wisatawan dari luar kota yang ingin mengunjungi tempat wisata dipulau ini. sehingga para wisatawan tidak tahu lokasi-lokasi wisata yang ingin dikunjungi. Selain sulitnya mencari lokasi wisata, wisatawan juga masih kesulitan dalam mencari tempat penginapan atau hotel. 
Selain objek wisata, pulau Lombok juga memiliki daya tarik dalam sektor budaya atau adat yang sampai sekarang masih kental dilingkungan masyarakat setempat. Budaya atau adat yang dimiliki setiap kabupaten berbeda-beda sehingga ragam budaya yang dimiliki sangat banyak.

Dengan ragam pariwisata dan budaya yang terdapat di pulau lombok, maka perlu adanya sistem informasi yang menyediakan informasi lokasi wisata serta rute jalan menuju lokasi wisata dan informasi tentang tempat penginapan atau hotel. Sehingga dengan adanya sistem informasi seperti ini dapat memudahkan wisatawan untuk menemukan lokasi wisata serta mempermudah wisatawan untuk mencari tempat penginapan.

\section{Landasan Teori}

\subsection{Kajian Penelitian Terdahulu}

Berdasarkan penelitian yang dilakukan oleh Lalu Wiratmaja (2015) menghasilkan sebuah sistem informasi geografis tentang objek wisata pada kabupaten Lombok Tengah berdasarkan kecamatan yang akan memberikan kemudahan-kemudahan kepada masyarakat atau wisatawan untuk menemukan tempat-tempat wisata yang ada di Kabupaten Lombok Tengah serta menyediakan ruterute menuju tempat wisata tersebut. aplikasi yang dihasilkan ini dapat mempermudah wisatawan untuk menemukan tempat wisata yang ada di kabupaten Lombok tengah. Namun kurangnya aplikasi ini, hanya menampilkan letak wisata yang ada di Kabupaten Lombok tengah saja.

Berdasarkan penelitian yang di lakukan oleh M. Junius Effendi (2013), menghasilkan sebuah sistem informasi geografis obyek wisata pada Dinas Kebudayaan dan Pariwisata pada Kota Pagaralam yang akan memberikan kemudahan pihak dinas dan masyarakat dalam proses pencarrian informasi mengenai obyek-obyek wisata yang terdapa di Kota Pagaralam maupun informasi mengenai event atau acara yang di selenggarakan oleh Dinas Kebudayaan dan Pariwisata yang terdapat pada Kota Pagaralam. Aplikasi yang di di hasilkan ini dapat mempermudah dalam proses penyimpanan dan penambahan data obyek wisata serta akan lebih menghemat waktu dalam proses pencarian waktu. Namun kurangnya system ini adalah hanya menampilkan informasi obyek wisata saja tanpa menampilkan peta wilayah ataupun rute perjalanan menuju obyek-obyek wisata.

\subsection{Yii Framework}

Yii Framework atau lebih dikenal dengan sebutan Yii merupakan kerangka kerja open source berbasis PHP. Nama Yii merupakan singkatan dari "Yes It Is!". Seperti PHP Framework pada umumnya, Yii juga mengadopsi konsep MVC (Model - View - Controller).

Yii adalah kerangka kerja pemrograman umum Web yang bisa dipakai untuk mengembangkan semua jenis aplikasi Web. Oleh karena Yii sangat ringan dan dilengkapi dengan solusi caching yang memuaskan, ia sangat cocok untuk pengembangan aplikasi dengan lalu lintas-tinggi, seperti portal, forum, sistem manajemen konten (CMS), sistem e-commerce, dll.

\subsection{PHP (Perl Hypertext Preprocessor)}

PHP merupakan bahasa berbentuk skrip yang ditempatkan dalam server dan diproses di server (Prihatna, 2005).[7] PHP dibuat oleh Rasmus Lerdorf, diawali dengan membuatnya sebagai personal project dan disempurnakan oleh group six of developers dan lahir kembali dengan nama PHP.

Secara khusus, PHP dirancang untuk membuat web dinamis. Artinya, PHP dapat membentuk suatu tampilan berdasarkan permintaan. PHP meemiliki kemampuan yang baik dalam hal perhitungan matematika, dalam hal informasi jaringan e-mail dan regular expretion. Selain itu PHP juga mampu sebagai interface dengan database yang baik, support dengan bermacam-macam database server seperti MySQL, ORACLE, Sysbase. 


\section{Metode}

\subsection{Wawancara}

Metode wawancara ini dilakukan dengan beberapa narasumber antara lain:

- Staf kantor dinas kebudayaan dan pariwisata kota Mataram

Wawancara dilakukan dengan H. Drs. Lalu Ridwan yang bertugas di bagian Humas. Wawancara dilakukan dengan sesi tanya jawab terkait dengan tempat-tempat wisata dan kebudayaan ataupun festival yang masig rutin diadakan oleh pemerintah kota mataram.

- Warga

Wawancara dilakukan dengan beberapa warga yang tinggal disekitar tempat-tempat wisata dengan beberapa sesi tanya jawab seputar kebudayaan yang masih kental dan masih sering dilakukan oleh masyarakat setempat.

\subsection{Analisis kebutuhan}

Analisis kebutuhan pengguna Menganalisis pengguna yang terlibat dalam sistem berdasarkan tugas dan fungsi masing-masing. Kebutuhan pengguna dalam sistem ini antara lain:

- Admin

Yaitu pengelola website yang bertugas untuk menambah, edit, dan mengupdate informasi di dalam website.

- Warga / wisatawan

Mengakses web untuk mendapatkan informasi tentang tempat-tempat wisata yang ingin dikunjungi, jasa travelling dan informasi tentang tempat penginapan (hotel).

\section{Hasil dan Pembahasan}

\subsection{Tampilan Frontend Halaman utama User}

Pada gambar 4.1 merupakan Halaman utama atau index yang pertama kali akan muncul ketika pengguna memasukkan alamat website pariwisata Pulau Lombok. Halaman utama ini terdiri dari beberapa menu utama seperti : menu Home, menu wisata, menu budaya, menu makanan, menu reservasi hotel, menu guide, menu event dan menu Contact.

Gambar 4.1 tampilan halaman utama use

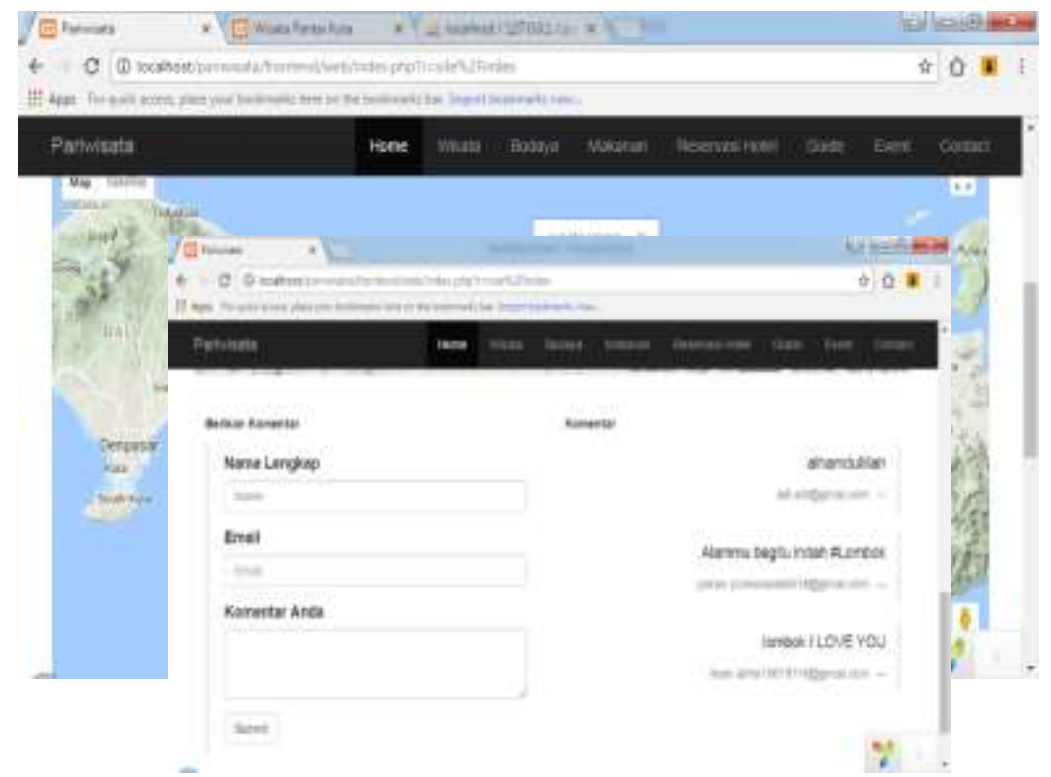

Pada halaman menu utama ini juga terdapat testimoni seperti yang terlihat pada gambar 4.2 dibawah ini. dimana user dapat memberikan komentar mengenai tempat-tempat wisata, budaya, makanan, hotel, event, dan user juga dapat memberikan komentar tentang sistem ini. 


\subsubsection{Tampilan halaman Backend sistem menu utama admin}

Pada gambar 4.2 merupakan tampilan halaman utama pada backend sistem. Pada halaman ini, admin dapat menambah, mengedit dan menghapus informasi yang akan ditampilkan pada halaman frontend sistem.

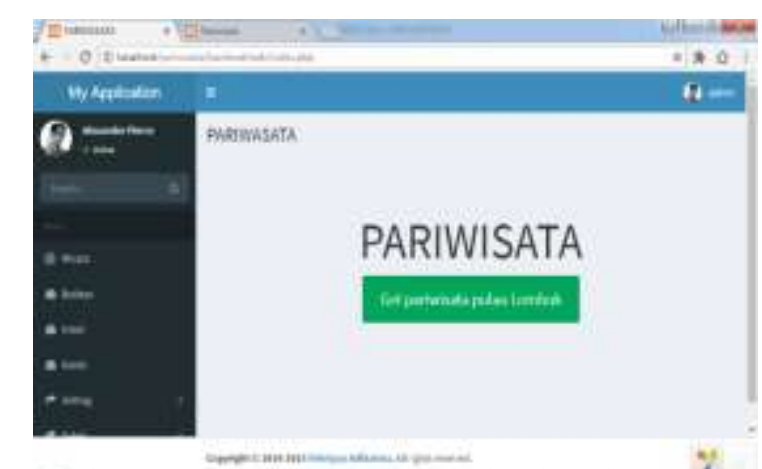

Gambar 4.3 tampilan halaman backend user

\subsubsection{Tampilan pencarian rute jalan}

Halaman ini merupakan tampilan untuk mencari rute jalan ke tempat yang ingin user kunjungi. Pada halaman ini, user hanya perlu memasukkan tempat awal kemudian user memilih tujuan yang telah tersedia. Seperti yang terlihat pada gambar 4.3 dibawah ini.

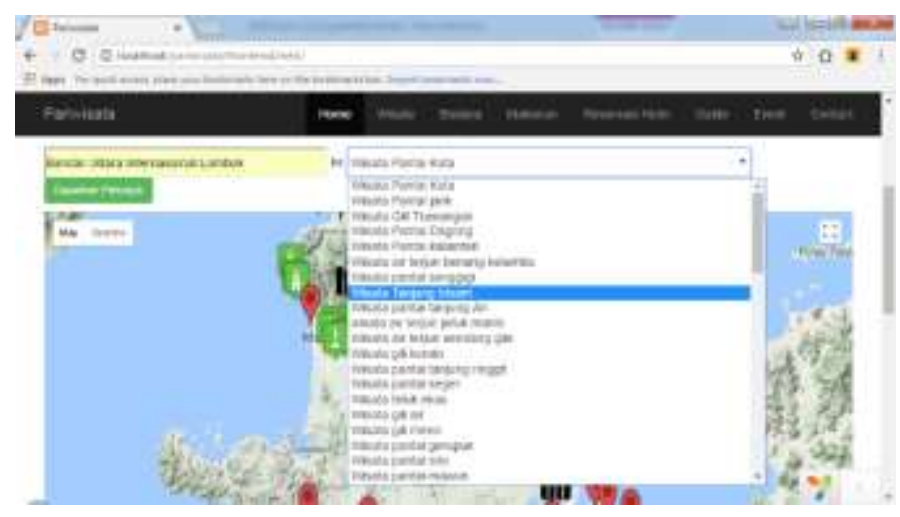

Gambar 4.4 tampilan pencarian rute jalan

\subsubsection{Tampilan halaman menu wisata}

Pada gambar 4.4 ini merupakan halaman menu wisata. Dimana user dapat melihat pilihan-pilihan wisata yang ada di sistem ini. user juga dapat melihat deskripsi dari wisata yang dipilih dengan mengklik button detail. 

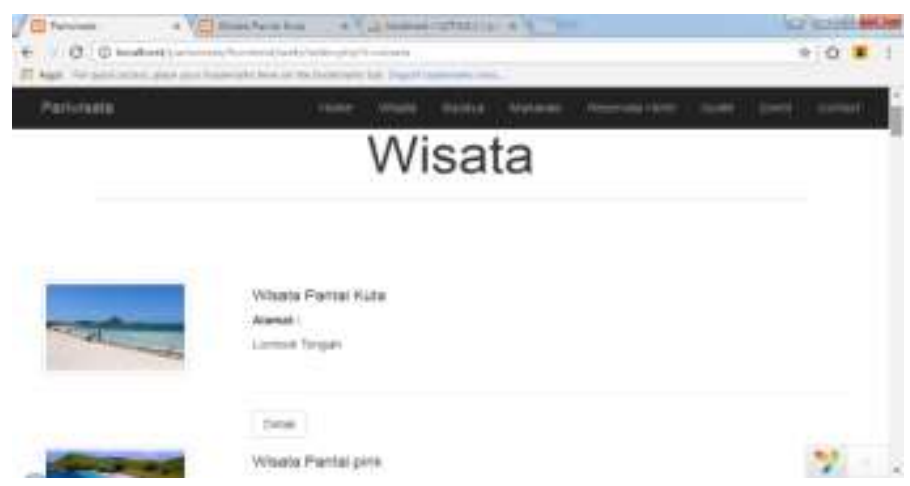

Gambar 4.5 tampilan halaman menu wisata

\subsubsection{Tampilan halaman menu event}

Pada gambar 4.5 ini merupakan halaman menu event. Dimana user dapat melihat eventevent apa saja yang ada dalam sistem. Pada halaman ini juga user dapat melakukan pencarian event berdasarkan bulan yang diinginkan. User juga dapat melihat deskripsi dari event yang dipilih dengan mengklik button detail.

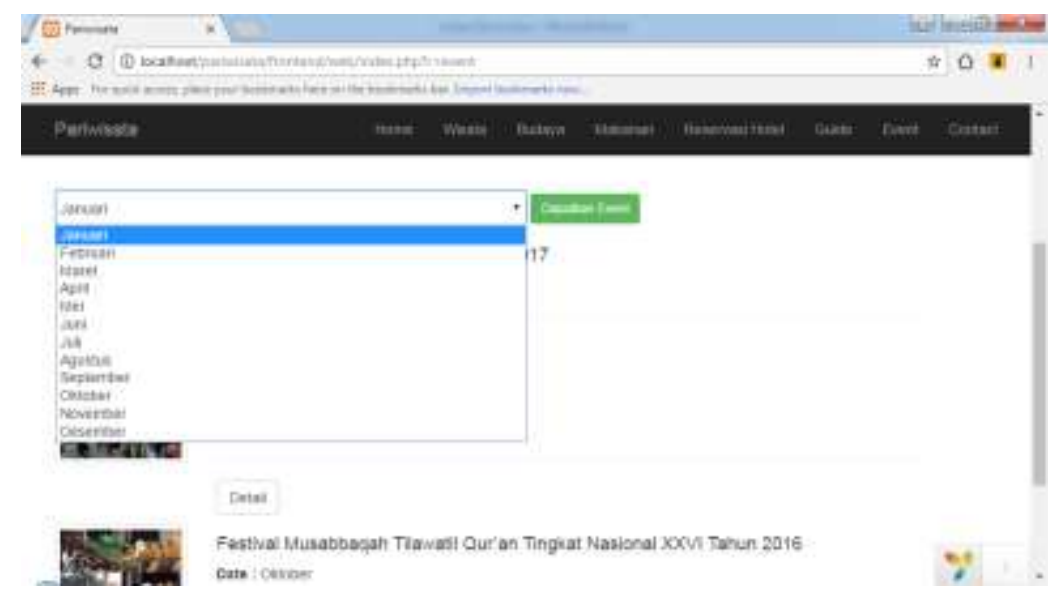

Gambar 4.6 tampilan halaman menu event

\section{Penutup}

5.1 Kesimpulan

Dari hasil penelitian ini, dapat diambil kesimpulan bahwa telah dihasilkan suatu Sistem Informasi Geografis Berbasis Web untuk pariwisata pulau Lombok, yang dapat membantu Dinas Pariwisata dan Kebudayaan kota Mataram Nusa Tenggara Barat untuk menginformasikan wisata dan budaya kepada masyarakat atau wisatawan secara efektif dan efisien

\subsection{Saran}

Saran yang dapat diberikan untuk pengembangan sistem ini selanjutnya adalah sebagai berikut :

1. Menambah fasilitas keamanan agar sistem yang dibuat tidak dapat di-hacking atau dicuri oleh orang yang tidak berwenang

2. Website ini dapat dikembangkan menjadi lebih menarik dan lebih lengkap dengan menambahkan fitur-fitur seperti informasi tempat kuliner, travel agent dan fasilitasfasilitas lain yang dibutuhkan oleh wisatawan. 


\section{DAFTAR PUSTAKA}

1. http://www.ntbprov.go.id/hal-sejarah-nusa-tenggara-barat.html (di akses pada tanggal 23 Desember 2016).

2. http://www.kompasiana.com/www.kompasiana.commardinahpkn/budaya-di-lombokntb_552acada6ea834d456552d23 (di akses pada tanggal 23 Desember 2016).

3. Lalu Wiratmaja,. (2015) sistem informasi geografis berbasis web untuk pariwisata di Kabupaten Lombok Tengah, Nusa Tenggara Barat.

4. Effendi, Junius, M., 2010, Sistem Informasi Geografis Obyek Wisata pada Dinas Kebudayaan dan Pariwisata Kota Pagaralam Berbasis Web. Pagaralam.

5. Prahasta, Eddy., 2005, sistem informasi geografis, informatika, Bandung.

6. http://www.yiiframework.com/doc/guide/1.0/id/quickstart.what-is-yii (diakses pada tanggal 6 September 2017)

7. Prihatna, H., 2005, Kiat Praktis Menjadi Webmaster Profesional, Elex Media Komputindo, Jakarta 